\title{
HISTOLOGI LIMPA DAN HEMATOLOGI MENCIT YANG DIINFEKSI Escherichia coli SETELAH PEMBERIAN ASAM HUMAT GAMBUT KALIMANTAN
}

\section{Spleen Histology and Hematology of Mice Infected by Escherichia coli after Oral Administration of Humic Acid from Borneo Peat}

\author{
Diah Wulandari Rousdy, Elvi Rusmiyanto Pancaning Wardoyo* \\ Jurusan Biologi, Fakultas MIPA, Universitas Tanjungpura. Jl. Prof. DR. Hadari Nawawi, Pontianak 78111 \\ *Email: elvirusm1971@gmail.com
}

\begin{abstract}
Humic acid compounds have an immunostimulatory effect. The aim of this research was to determine the effect of humic acid on the spleen of mice infected with Escherichia coli. The study used a completely randomized design with six treatments and five replicates. The treatments were normal control, negative control, positive control of isoprinosine, humic acid dose of 62.5; 125; and $250 \mathrm{mg} / \mathrm{kg}$ body weight (BW). The results showed that $\mathrm{E}$. coli infection caused diarrhea symptoms and significant weight loss. There were significant differences $(P<0.05)$ on hematocrit value and a total leukocyte count of humic acid, in which isoprinosine treatment was higher than those of negative control and normal control. There was no significant difference in the spleen weight of the mice subjected to the different treatments, but through histologic observations a significant difference $(P<0.05)$ was found in the histologic size of the spleen. Humic acid treatment of 250 and $125 \mathrm{mg} / \mathrm{kg} \mathrm{BW}$ resulted in the widest white pulp $(495.8 \pm 58.2 \mu \mathrm{m})$ and the highest leukocytes count $(6725 \pm 1018$ cell/mL), respectively. On the red pulp serving as negative control numerous clusters of lymphocyte cells were found.
\end{abstract}

Keywords: Escherichia coli, humic acid, peat soil, spleen, white pulp

\begin{abstract}
ABSTRAK
Senyawa asam humat mempunyai potensi imunostimulan. Penelitian ini bertujuan mengetahui pengaruh pemberian asam humat terhadap organ limpa mencit yang diinfeksi bakteri Escherichia coli. Penelitian ini menggunakan rancangan acak lengkap dengan enam perlakuan dan lima ulangan. Perlakuan tersebut yakni kontrol normal, kontrol negatif, kontrol positif isoprinosin, asam humat dosis 62,$5 ; 125$; dan $250 \mathrm{mg} / \mathrm{kg}$ berat badan (BB). Hasil penelitian menunjukkan bahwa infeksi bakteri $E$. coli pada mencit menyebabkan mencit mengalami gejala diare dan penurunan berat badan yang signifikan. Perbedaan signifikan $(P<0,05)$ pada nilai hematokrit dan jumlah leukosit total perlakuan asam humat dan isoprinosin lebih tinggi dibandingkan kontrol negatif dan kontrol normal. Tidak terdapat perbedaan nyata $(P>0,05)$ pada berat limpa mencit antar perlakuan, melalui pengamatan histologi ditemukan perbedaan ukuran histologi limpa mencit. Perlakuan asam humat 250 $\mathrm{mg} / \mathrm{kg}$ BB mempunyai ukuran pulpa putih $(495,8 \pm 58,2 \mu \mathrm{m})$ dan perlakuan asam humat 125 $\mathrm{mg} / \mathrm{kg}$ BB mempunyai nilai leukosit tertinggi $(6725 \pm 1018 \mathrm{sel} / \mathrm{mL})$. Pada pulpa merah perlakuan kontrol negatif ditemukan banyak sel limfosit yang menggerombol.
\end{abstract}

Kata Kunci: asam humat, Escherichia coli, limpa, pulpa putih, tanah gambut 


\section{PENDAHULUAN}

Gambut terbentuk dari bahan organik terutama sisa tumbuhan yang tertimbun dalam keadaan basah berlebih, tidak padat dan lambat terdekomposisi. Karakteristik kimia yang paling khas dari tanah gambut adalah tingginya kandungan humus atau bahan organik tanah (Noor 2001). Humus dalam tanah gambut terbagi menjadi tiga komponen utama yakni asam humat, asam fulvat dan hemin. Asam humat merupakan substansi humus yang paling dominan menyusun gambut.

Struktur molekul asam humat dari tanah gambut tropis seperti di Indonesia berbeda dengan tanah gambut subtropis yang telah banyak diteliti (Orlov 1995; Stevenson 1994). Perbedaan struktur molekul asam humat dipengaruhi oleh faktor pembentuk humus seperti jenis tumbuhan. Perbedaan struktur molekul ini juga mencerminkan perbedaan fungsi biologis dari asam humat.

Asam humat mempunyai potensi antioksidan atau kemampuan menangkap radikal bebas disebabkan oleh banyaknya gugus oksigen reaktif seperti karboksil, hidroksil dan keton. Percobaan secara in vitro dilakukan oleh Vašková et al. (2011), asam humat subtropis mampu menangkap radikal hidroksil dan tidak mencetuskan produksi radikal oksidatif lain.

Respon fisiologis lain dari pemberian asam humat adalah stimulasi sistem imunitas, sehingga asam humat berpotensi sebagai imunostimulan. Junek et al. (2009) menyatakan asam humat mempunyai efek bimodel tergantung konsentrasi dalam menstimulus dan menekan sistem imunitas. Hal ini berkaitan dengan pengaktifan gen NF-kB yang mengkode pembentukan interleukin dan TNF-a. Selain itu, Rousdy et al. (2016) menemukan bahwa pemberian asam humat dari gambut tropis Kalimantan mampu menstimulus sistem imunitas hewan berupa peningkatan aktivitas fagositosis dan peningkatan jumlah leukosit. Rousdy dan Wijayanti (2016) juga menambahkan suplementasi asam humat dalam pakan ikan mampu meningkatkan berat badan ikan mas dan meningkatkan respons imunitas nonspesifik.

Escherichia coli merupakan salah satu dari bakteri enterik dan anggota flora usus normal. Bakteri ini bersifat patogen apabila berada di luar usus atau di lokasi lain di mana flora normal jarang ditemukan. Pada kondisi pertahanan tubuh inang yang tidak berada dalam kondisi optimal, bakteri ini dapat menimbulkan infeksi lokal yang mencapai aliran darah dan menimbulkan sepsis.

Infeksi akibat E. coli akan mengaktivasi sistem imunitas tubuh. Limpa mengandung banyak makrofag dan merupakan tempat pembentukan limfosit aktif dan antibodi. Sel-sel limfosit yang berperan dalam imunitas spesifik, berkumpul dan berproliferasi dalam germinal center. Peningkatan aktivitas sistem imun ditandai dengan perubahan diameter pulpa putih dan germinal center (Tasminatun et al. 2017; Kalia et al. 2016).

Adanya kontak erat antara sel-sel limfosit dalam limpa dengan sirkulasi darah sangat berperan dalam pertahanan tubuh terhadap mikroorganisme dan antigen asing lain. Organ limpa akan memberikan respon masuknya antigen asing ke dalam tubuh berupa penambahan diameter germinal center yang merupakan pusat maturasi limfosit. Penambahan diameter germinal center juga terjadi pada penambahan imunostimulan (Matheos et al. 2013; Winarni et al. 2013). Berdasarkan hal tersebut perlu dilakukan penelitian mengenai pengaruh pemberian asam humat terhadap mencit yang diinfeksi $E$. coli berdasarkan parameter histologi limpa.

\section{BAHAN DAN METODE}

\section{Bahan}

Penelitian dilaksanakan selama 5 bulan mulai bulan Mei-Oktober 2017 di Laboratorium Biologi dan Laboratorium Zoologi Fakultas MIPA Universitas Tanjungpura. Peralatan yang digunakan dalam penelitian antara lain: perangkat pemeliharaan hewan uji, peralatan gelas, gelas objek, hemositometer, mikrohematokrit, gelas objek, mikrotom putar, sentrifuse dan seperangkat pembuatan mikroteknik hewan.

Bahan kimia yang digunakan antara lain: larutan $\mathrm{NaOH} 0,1 \mathrm{M}$, larutan $\mathrm{HCl} 6 \mathrm{M}$, akuades, isoprinosine, etanol dengan konsentrasi bertingkat, xylol, parafin, canada balsam, hematoksilin, eosin, klorofom, 
larutan buffer neutral formaline (BNF), larutan phospate buffer saline (PBS) steril dan biakan murni bakteri $E$. coli koleksi Laboratorium Mikrobiologi, Fakultas MIPA, Universitas Tanjungpura.

Hewan uji yang digunakan adalah mencit (Mus musculus L.) galur Swiss jantan dengan kisaran umur 2-3 bulan dan berat badan 20-40 gram. Mencit diaklimasi selama tujuh hari dengan pemberian makan dan minum secara ad libitum.

Tanah gambut diambil pada tingkat kematangan sapris di kedalaman $30-50 \mathrm{~cm}$ dari permukaan tanah. Jenis tanah diidentifikasi di Laboratorium Fisika Tanah Fakultas Pertanian Universitas Tanjungpura. Pemisahan asam humat mengacu pada metode IHSS (2015) yakni berdasarkan pengendapan dalam asam kuat dan kelarutan dalam basa lemah (Gambar 1).

\section{Rancangan percobaan}

Penelitian menggunakan Rancangan Acak Lengkap satu jalur. Tiga puluh hewan uji dibagi menjadi 6 perlakuan. Perlakuan yang diberikan sebagai berikut: Kontrol normal: mencit tidak diinjeksi bakteri $E$. coli dan asam humat; kontrol negatif: mencit diinjeksi bakteri $E$. coli dan tanpa pemberian asam humat; kontrol positif: mencit diinjeksi bakteri $E$. coli dan diberi obat isoprinosin; perlakuan asam humat $250 \mathrm{mg} / \mathrm{kg}$ BB: mencit diinjeksi bakteri $E$. coli dan diberi asam humat $250 \mathrm{mg} / \mathrm{kg} \mathrm{BB}$; perlakuan asam humat $125 \mathrm{mg} / \mathrm{kg} \mathrm{BB}$ : mencit diinjeksi bakteri $E$. coli dan diberi asam humat $125 \mathrm{mg} / \mathrm{kg}$ BB; perlakuan asam humat $62,5 \mathrm{mg} / \mathrm{kg}$ BB: mencit diinjeksi $E$. coli dan diberi asam humat $62,5 \mathrm{mg} / \mathrm{kg}$. Pemberian asam humat dilakukan secara oral menggunakan sonde lambung sesuai dosis perlakuan.

\section{Infeksi hewan uji}

Hewan uji mencit diinfeksi dengan 0,5 $\mathrm{mL} /$ hari suspensi bakteri E. coli $\left(10^{6} \mathrm{cfu} / \mathrm{mL}\right)$ yang disuntik secara intraperitoneal pada bagian abdomen (Mattheos et al. 2013). Infeksi dilakukan selama 5 hari. Kelompok kontrol negatif dilakukan terminasi pada hari ke-8 dan dibedah untuk mengambil organ limpa dan darahnya melalui jantung. Kontrol positif dan perlakuan asam humat, pemberian isoprinosin dan asam humat masing-masing dilakukan selama 7 hari, pada hari ke-8 mencit diinfeksi dengan bakteri $E$. coli selama 5 hari menggunakan dosis $10^{6} \mathrm{cfu} / \mathrm{mL}$ sebanyak $0,5 \mathrm{~mL} /$ hari.

\section{Pembuatan preparat limpa}

Mencit dibius dengan kloroform dan dibedah. Limpa yang berada di abdomen sebelah kiri berwarna merah kehitaman diambil dan dicuci dalam larutan PBS. Limpa dan hati ditimbang dengan timbangan analitik untuk mengetahui bobotnya. Limpa difiksasi dengan BNF kemudian dibuat preparat histologi menggunakan metode parafin dan pewarnaan hematoksilin eosin (HE) (Suvarna et al. 2013).

Bagian jaringan limpa yang diamati adalah diameter pulpa putih, germinal center dan zona marginalis. Diameter germinal center limpa diukur di bawah mikroskop pada perbesaran 40×. Diameter germinal center adalah rerata diameter yang ditentukan dari hasil pengukuran diameter terpanjang dan terpendek. Tiap individu diamati 3 irisan dan tiap irisan diamati 5 germinal center.

\section{Pemeriksaan hematokrit}

Pemeriksaan parameter hematologi menggunakan darah yang diambil langsung dari jantung (cardiac puncture) pada hari ke8. Penghitungan nilai hematokrit dengan cara darah dimasukkan ke dalam mikrokapiler dan disentrifugasi pada kecepatan $5000 \mathrm{rpm}$ selama 5 menit. Total leukosit dihitung menggunakan hemositometer.

\section{Analisis statistik}

Data pengamatan hematologi dan histologi limpa dianalisis statistik dengan

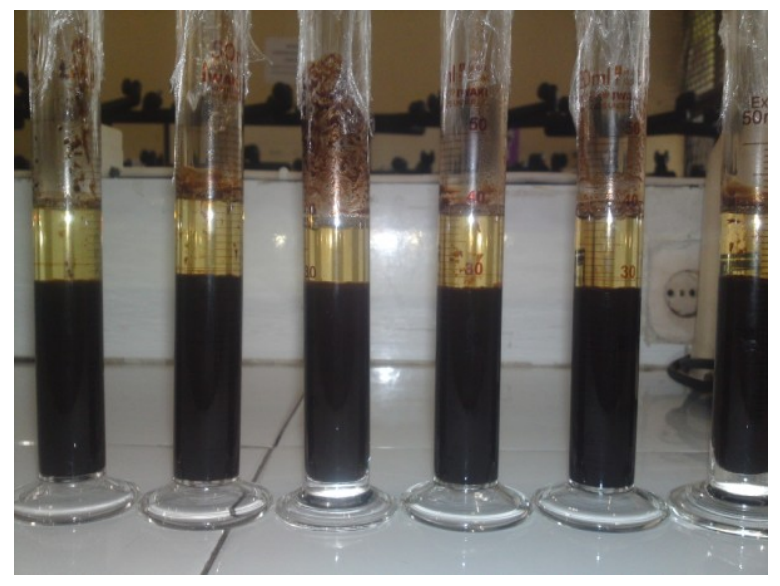

Gambar 1. Pemisahan asam humat dan asam fulvat 
Analysis of Variance (ANOVA) satu jalur. Apabila terdapat perbedaan antar perlakuan $(\mathrm{P}<0,05)$ dilanjutkan dengan uji lanjut Duncan's Multiple Range Test (DMRT) menggunakan SPSS versi 15.

\section{HASIL DAN PEMBAHASAN}

Berdasarkan hasil perlakuan, mencit (Mus musculus) yang diinfeksi oleh bakteri E. coli menunjukkan terjadinya gejala diare berupa meningkatnya frekuensi buang air besar, konsistensi feses yang encer dan berbau serta terjadi penurunan berat badan. Penurunan berat badan mencit terjadi pada semua perlakuan mencit yang diinfeksi bakteri E. coli, kecuali pada perlakuan kontrol normal yang tidak diinfeksi bakteri $E$. coli (Gambar 2.).

Mencit pada perlakuan normal mempunyai berat badan relatif konstan sebab tidak mengalami diare akibat pemberian bakteri E. coli. Penurunan berat badan terbesar terjadi pada perlakuan isoprinosin.

\section{Perubahan berat limpa dan hati}

Setelah pemberian perlakuan imunostimulan dan infeksi oleh bakteri $E$. coli, mencit dibedah untuk diamati perubahan pada organ hati dan limpa. Penimbangan berat limpa mencit pada semua kelompok perlakuan menunjukkan tidak ada perbedaan nyata $(P>0,05)$ (Gambar 3). Terdapat kecenderungan pada perlakuan isoprinosin mempunyai berat

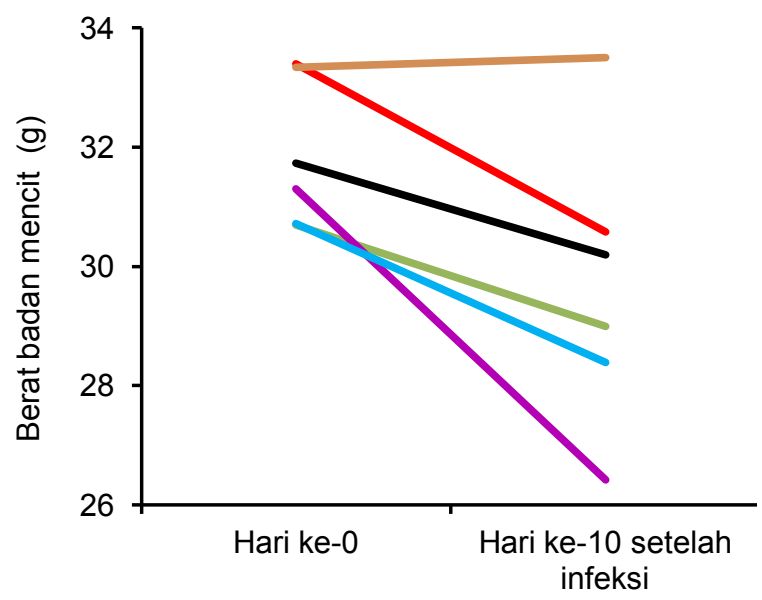

Gambar 2. Berat badan mencit sebelum dan setelah infeksi untuk perlakuan $\mathrm{AH} 62,5 \mathrm{mg} / \mathrm{kg}$ (一), $\mathrm{AH} 125 \mathrm{mg} / \mathrm{kg}$ (-), $\mathrm{AH} 250$ $\mathrm{mg} / \mathrm{kg} \mathrm{(-)}$, isoprinosin (-),kontrol negatif $(-)$, dan kontrol normal $(\stackrel{-}{-}$ limpa paling ringan dibandingkan perlakuan lainnya. Penurunan berat limpa pada kelompok isoprinosin kemungkinan disebabkan oleh infeksi berat yang terjadi pada perlakuan tersebut. Imunostimulan isoprinosin tidak berperan sebagai antibakteri sehingga tidak optimal dalam mengurangi diare pada mencit.

Pemberian asam humat pada dosis tertinggi cenderung meningkatkan berat limpa. Perubahan dari berat limpa disebabkan proses stimulasi pulpa putih limpa oleh pemberian imunostimulan asam humat. Asam humat juga diketahui mempunyai potensi sebagai antibakteri sehingga selain menstimulus sistem imunitas, asam humat juga mampu mengurangi jumlah bakteri patogen yang masuk ke dalam tubuh.

Hampir sejalan dengan berat limpa, pengamatan pada berat hati mencit menunjukkan perlakuan isoprinosin memberikan penurunan berat hati signifikan dibandingkan perlakuan lain (Tabel 1, Gambar 3). Hal ini kemungkinan disebabkan obat isoprinosin mengalami metabolisme utama dalam hati sehingga meningkatkan aktivitas dan fungsi hati. Asam humat sebagai obat alami yang diberikan tidak memberikan pengaruh pada berat hati secara signifikan. Begitu pula pada kontrol negatif dan kontrol normal yang tidak mendapat pengaruh senyawa apapun, tidak menunjukkan perubahan pada berat hati.

\section{Nilai hematokrit dan leukosit total}

Infeksi bakteri $E$. coli yang diberikan menyebabkan meningkatnya jumlah sel

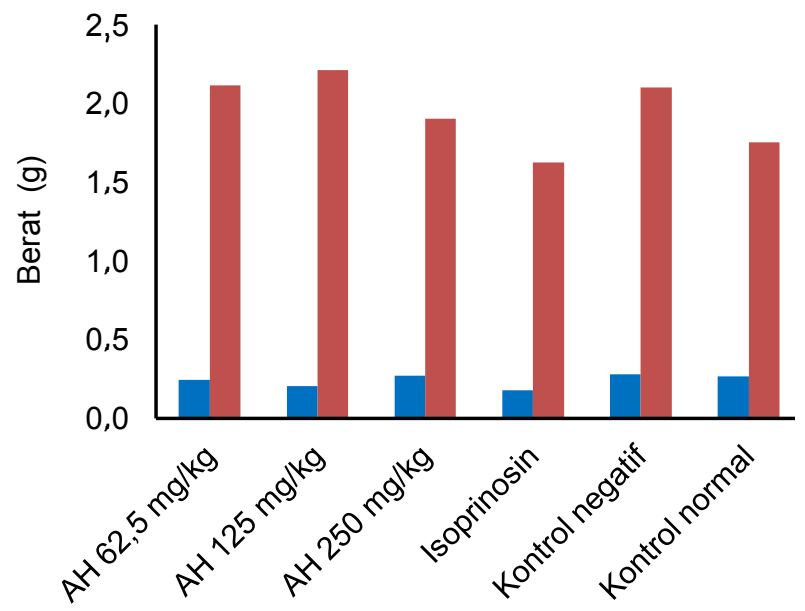

Gambar 3. Berat limpa ( $\square$ ) dan berat hepar ( $\square$ ) mencit 
Tabel 2. Ukuran histologi limpa

\begin{tabular}{|c|c|c|c|}
\hline Perlakuan & $\begin{array}{c}\text { Diameter pulpa } \\
\text { putih }(\mu \mathrm{m})\end{array}$ & $\begin{array}{l}\text { Diameter germinal } \\
\text { center }(\mu \mathrm{m})\end{array}$ & $\begin{array}{c}\text { Lebar zona } \\
\text { marginalis }(\mu \mathrm{m})\end{array}$ \\
\hline Asam humat $62,5 \mathrm{mg} / \mathrm{kg}$ & $404,2 \pm 89,1^{\mathrm{bc}}$ & $150,0 \pm 53,7^{a}$ & $95,0 \pm 57,6^{a}$ \\
\hline Asam humat 125 mg/kg & $433,3 \pm 86,2^{c}$ & $128,3 \pm 43,7^{\mathrm{a}}$ & $65,0 \pm 22,8^{b}$ \\
\hline Asam humat 250 mg/kg & $495,8 \pm 58,2^{d}$ & $128,3 \pm 43,6^{a}$ & $65,0 \pm 22,8^{b}$ \\
\hline Isoprinosin & $308,3 \pm 46,9^{a}$ & $129,2 \pm 35,8^{a}$ & $55,8 \pm 15,0^{b}$ \\
\hline Kontrol negatif & $354,2 \pm 65,6^{\mathrm{ab}}$ & $114,2 \pm 27,8^{\mathrm{a}}$ & $49,2 \pm 2,9^{b}$ \\
\hline
\end{tabular}

Keterangan: huruf yang berbeda pada kolom yang sama menunjukkan perbedaan nyata antar perlakuan $(P<0,05)$

Tabel 1. Nilai hematokrit dan leukosit total

\begin{tabular}{lcc}
\hline Perlakuan & Hematokrit (\%) & Leukosit (sel/mL) \\
\hline Asam humat $62,5 \mathrm{mg} / \mathrm{kg}$ & $84,0 \pm 6,365^{\mathrm{c}}$ & $6075 \pm 1926^{\mathrm{ab}}$ \\
Asam humat $125 \mathrm{mg} / \mathrm{kg}$ & $56,0 \pm 11,547^{\mathrm{ab}}$ & $6725 \pm 1018^{\mathrm{ab}}$ \\
Asam humat $250 \mathrm{mg} / \mathrm{kg}$ & $48,8 \pm 9,738^{\mathrm{a}}$ & $6525 \pm 194^{\mathrm{ab}}$ \\
Isoprinosin & $62,4 \pm 11,158^{\mathrm{ab}}$ & $8237 \pm 2784^{\mathrm{b}}$ \\
Kontrol negatif & $62,2 \pm 11,555^{\mathrm{ab}}$ & $5535 \pm 1665^{\mathrm{a}}$ \\
\hline
\end{tabular}

Keterangan: huruf yang berbeda pada kolom yang sama menunjukkan perbedaan nyata antar perlakuan $(P<0,05)$

darah putih (leukosit) pada semua perlakuan kecuali kontrol normal (Tabel 1, Gambar 4). Sel leukosit merupakan jenis sel darah yang berperan mempertahankan tubuh terhadap infeksi bakteri E. coli. Perlakuan asam humat dan obat isoprinosin memberikan nilai leukosit lebih tinggi dibandingkan kontrol negatif yang tidak mendapat imunostimulan apapun. Perlakuan kontrol normal yang tidak mendapat infeksi mempunyai jumlah leukosit standar yakni sekitar $4.468 \mathrm{sel} / \mathrm{mL}$ darah.

Jumlah total leukosit meningkat dalam darah apabila terjadi infeksi akibat bakteri patogen. Kalia et al. (2016) melaporkan infeksi bakteri Salmonella enterica serovar Typhimurium secara intraperitoneal pada mencit Balb/C akan meningkatkan nilai total leukosit dan persentase limfosit. Jumlah eritrosit dan persentase hematokrit akan menurun pada perlakuan infeksi bakteri Salmonella.

Pemberian asam humat pada konsentrasi rendah $62,5 \mathrm{mg} / \mathrm{kg}$ BB diduga menstimulasi proliferasi sel darah merah. Proliferasi sel darah merah atau eritrosit ditunjukkan dengan besarnya nilai hematokrit pada mencit perlakuan asam humat $62,5 \mathrm{mg} / \mathrm{kg}$. Pemberian asam humat dosis tertinggi $250 \mathrm{mg} / \mathrm{kg}$ menyebabkan penurunan hematokrit. Penurunan hematokrit pada konsentrasi asam humat
$250 \mathrm{mg} / \mathrm{kg}$ diduga disebabkan efek khelator asam humat yang dapat mengikat logam Fe. Logam Fe diperlukan dalam pembentukan hemoglobin dan sel darah merah.

Asam humat mempunyai banyak gugus fungsi reaktif seperti karboksil dan hidroksil yang mudah mengalami ionisasi. Proses ini menyebabkan senyawa humat menjadi bermuatan negatif (polianionic compound) dan mudah mengikat kationkation (Stevenson 1994). Tan (2003) dalam Lasmi (2013) menyatakan bahwa kemampuan tiap gugus fungsi reaktif asam humat untuk mengalami deprotonisasi menjadi senyawa polianionik sangat dipengaruhi oleh $\mathrm{pH}$ lingkungan. Hasil spektra inframerah asam humat tanah gambut Kalimantan diketahui mengandung gugus - $\mathrm{COOH}$ (Lasmi 2013), maka diduga pada $\mathrm{pH}$ netral ( $\mathrm{pH}$ plasma) gugus $-\mathrm{COOH}$ mengalami deprotonisasi lebih cepat. Hal ini menyebabkan asam humat tanah gambut lebih mudah mengkelat ion $\mathrm{Fe}^{2+}$ selama berada dalam aliran darah.

Hematokrit merupakan rasio jumlah sel darah merah terhadap total volume darah, dengan demikian peningkatan persentase hematokrit menunjukkan semakin banyaknya jumlah sel darah merah. Efek proliferatif pembentukan eritrosit akibat pemberian imunostimulan kemungkinan 
disebabkan peran IL-1, IL-3, IL-6 dan GMCSF (Chen et al. 2002) pada perkembangan sel induk eritrosit.

Peningkatan jumlah leukosit mencit selama proses imunostimulasi asam humat menunjukkan bahwa asam humat mampu memicu proliferasi sel-sel darah putih dalam jaringan hematopoietik. Sel darah putih memiliki peranan penting dalam sistem imun yakni sebagai pertahanan seluler terhadap infeksi patogen.

Efek proliferatif dari senyawa humat gambut dilaporkan dalam penelitian Obminska-Domoradzka dan Stefanska-
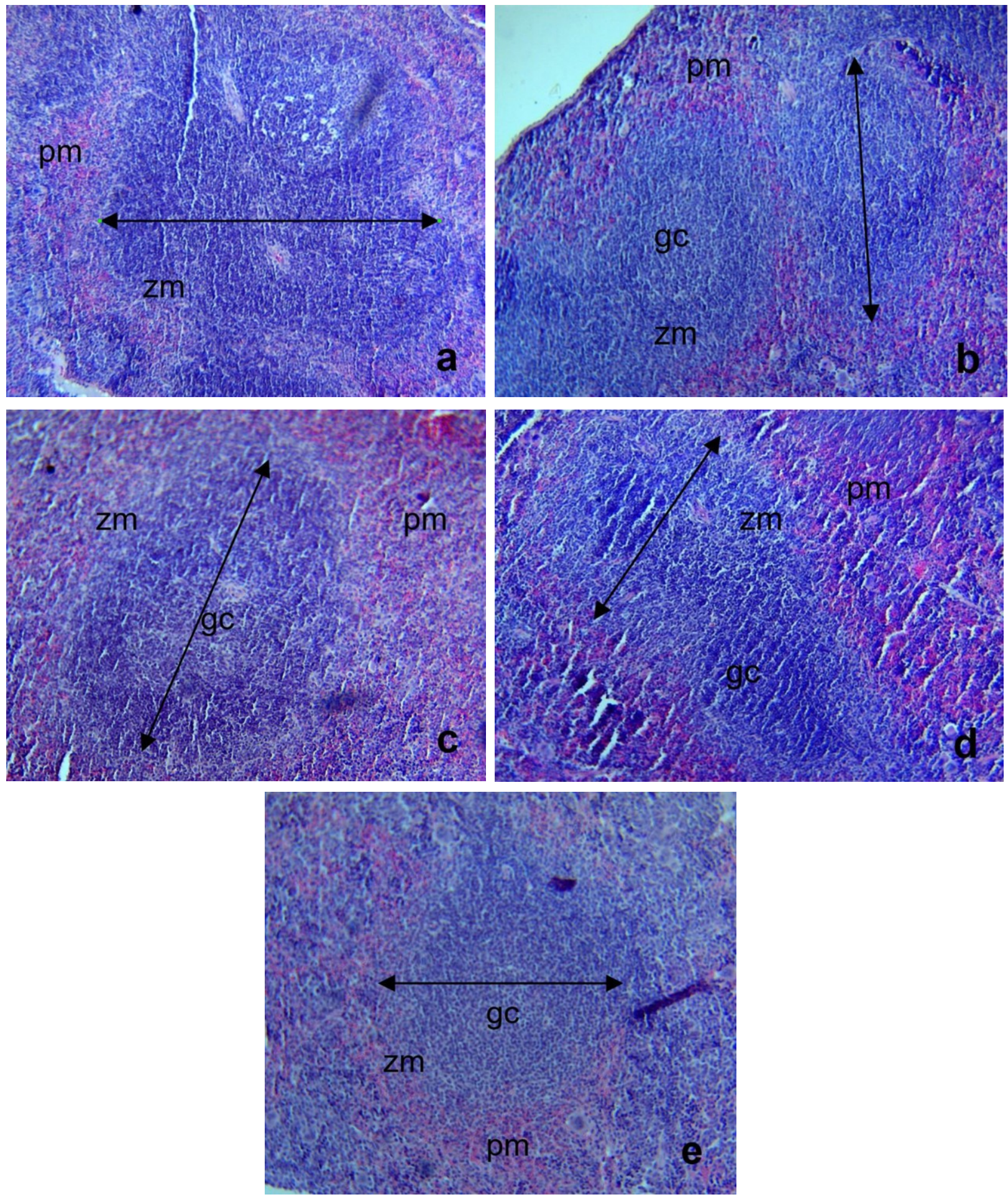

Gambar 4. Histologi Limpa (a) Asam Humat Dosis 62,5 mg/kg; (b) Asam Humat Dosis 125 mg/kg; (c) Asam Humat Dosis 250 mg/kg; (d) Kontrol Positif Isoprinosin; (e) Kontrol Negatif. Keterangan: germinal center (gc), pulpa merah $(\mathrm{pm})$, zona marginalis $(\mathrm{zm})$, pulpa putih $(\leftrightarrow)$. Perbesaran $100 \times$ 
Jonca (2001) dalam Habibian et al. (2010) menyatakan bahwa bahan gambut memiliki potensi meningkatkan kemampuan proliferatif sel timosit tikus yang distimulasi mitogen. Selain itu, asam humat diketahui mempunyai efek bimodal, dimana stimulasi imunitas terjadi pada pemberian asam humat dosis rendah, sedangkan inhibisi imunitas terjadi pada pemberian asam humat dosis tinggi (Junek et al. 2009; van Rensburg dan Naude 2009).

\section{Histologi limpa mencit}

Organ limpa mencit dibuat preparat sayatan dengan metode parafin dan pewarnaan hematoksilin. Bagian dalam parenkim limpa tersusun oleh pulpa merah dan pulpa putih. Pulpa putih tampak seperti nodul atau bulatan putih pada permukaan irisan limpa. Pulpa putih merupakan nodul limfoid atau kumpulan sel limfosit yang menyelubungi arteri sentralis, terutama jenis limfosit $\mathrm{T}$.

Diantara pulpa merah dan putih terdapat zona marginalis yang dipenuhi limfosit B. Pulpa merah limpa merupakan jaringan merah gelap yang dipenuhi darah. Penyusun pulpa merah berupa jaringan ikat retikulin, limfosit $B$, limfosit $T$, sel plasma dan banyak sel darah serta sinusoid.

Pada irisan preparat limpa tampak pulpa putih yang dikelilingi oleh pulpa merah. Pulpa merah terpulas kemerahan disebabkan pada bagian ini dipenuhi oleh kapiler darah atau sinus venosus.

Pada perlakuan kontrol negatif ditemukan sel limfosit dalam susunan klaster atau menggerombol pada pulpa merah (Gambar 4e). Tampilan limfosit pada pulpa merah yang khas kemungkinan disebabkan oleh reaksi antara antigen bakteri $E$. coli yang masuk ke tubuh dengan sel-sel leukosit. Tidak semua pulpa putih memiliki germinal center. Germinal center akan aktif dan membesar bila terjadi proses imunostimulasi pada sistem imun. Seperti pada kelompok kontrol negatif yang tidak diberikan imunostimulasi, pulpa putih dan germinal center yang diamati berukuran lebih kecil yakni rata-rata $354 \mu \mathrm{m}$ (Tabel 2).

Infeksi bakteri $E$. coli yang terjadi pada kontrol negatif tidak menyebabkan reaksi inflamasi yang ditandai dengan pembesaran pulpa putih dan germinal center. Pembesaran diameter pulpa putih dapat disebabkan oleh reaksi inflamasi. Tasminatun et al. (2017) melaporkan pemberian agen inflamasi ovalbumin akan meningkatkan diameter pulpa putih. Reaksi inflamasi disebabkan oleh pelepasan prostaglandin yang menyebabkan migrasi dan pengumpulan sel leukosit pada limpa. Kalia et al. (2016) menambahkan infeksi berat akibat bakteri akan menyebabkan pelebaran sinus limfa dan ekspansi sel eritrosit pada pulpa merah. Ciri ini merupakan tanda pembesaran limpa atau sphlenomegali. Pembesaran limpa dapat dilihat dari berat limpa kontrol negatif dan perlakuan asam humat mempunyai berat limpa lebih dibandingkan kontrol normal yang tidak mendapat infeksi bakteri $E$. coli.

Pada perlakuan asam humat 62,5 $\mathrm{mg} / \mathrm{kg}$ BB mempunya diameter pulpa putih paling kecil yakni 404,2 $\mu \mathrm{m}$ namun mempunyai diameter germinal center dan zona marginalis paling besar (Tabel 2). Pada bagian tengah pulpa putih tampak germinal center yang berisi sel-sel limfosit yang sedang mengalami maturasi. (Gambar 4a). Sel limfosit yang belum matang tampak berukuran lebih besar dibandingkan sel limfosit yang matang. Pulpa putih pada perlakuan asam humat $62,5 \mathrm{mg} / \mathrm{kg}$ berukuran lebih kecil, dengan zona marginalis yang lebih tipis. Zona marginalis berisi sel limfosit B. Bagian tepi dari zona marginalis tampak arteri centralis yang merupakan percabangan dari arteri trabekularis (Gambar 4).

Pada perlakuan isoprinosin (kontrol positif), pulpa putih limpa berukuran paling kecil dengan rata-rata $308 \mu \mathrm{m}$. Hal ini diduga ukuran pulpa putih akan berkorelasi dengan berat limpa. Berat limpa pada perlakuan isoprinosin paling rendah dibandingkan perlakuan lain (Tabel 2, Gambar 3). Hasil penelitian ini berbeda dengan Patil et al. (2012) yang menyatakan isoprinosin merupakan imunostimulan sintetis yang menyebabkan proliferasi pada sel $\mathrm{T}$ dan peningkatan berat limpa. Perbedaan hasil tersebut disebabkan oleh isoprinosin yang tidak memiliki aktivitas antibakteri sehingga infeksi $E$. coli pada mencit berakibat akut dan menurunkan berat badan serta berat limpa.

Perlakuan asam humat dosis 125 $\mathrm{mg} / \mathrm{kg}$ dan $250 \mathrm{mg} / \mathrm{kg}$ menyebabkan pulpa putih berukuran besar dengan germinal 
center dan zona marginalis yang lebih luas (Tabel 2). Pada pemberian asam humat dosis tertinggi yakni $250 \mathrm{mg} / \mathrm{kg}$ tampak bagian dalam pulpa putih tersusun oleh limfosit yang tidak rapat atau merenggang (Gambar 3c). Kondisi ini disebut sebagai kongesti limpa (Matheos et al. 2013). Susunan limfosit yang merenggang pada pulpa putih akan menyebabkan diameter pulpa putih menjadi lebih lebar (Tabel 2). Kondisi kongesti limpa juga ditemukan pada penelitian lain. Andrew et al. (2017) melaporkan dosis ekstrak bawang putih tertinggi dapat memicu kondisi anemia, penurunan jumlah oksigen dan kongesti pulpa putih limpa.

Pulpa putih dan germinal center merupakan tempat berkumpulnya sel limfosit khususnya sel limfosit T. Sedangkan sel limfosit $B$ berkumpul pada zona marginalis pulpa putih. Asam humat merupakan substansi humus yang berpotensi menstimulus proliferasi dan maturasi sel-sel leukosit, khususnya limfosit yang utama berkumpul pada organ limpa. Hal tersebut diduga berkaitan dengan stimulus produksi sitokin, suatu protein sinyal yang berperan penting dalam komunikasi antar sel leukosit.

Penelitian yang dilaporkan oleh Joone et al. (2003) menggunakan kultur sel limfosit manusia penderita HIV menyebutkan bahwa pemberian oxihumat (senyawa humat dari batu bara) akan meningkatkan proliferasi sel limfosit dan sekresi interleukin-2 (IL-2). Fungsi dari IL-2 berperan dalam menstimulus maturasi sel leukosit lain dalam tubuh. Stimulus pelepasan sitokin juga dilaporkan oleh Vetvitcka et al. (2010) yang menyatakan bahwa penggunaan asam humat bersama imunostimulan glukan (rasio 1:1) dapat menstimulus secara optimal sekresi enam jenis sitokin yakni IL-2, IL-4, IL-5, IL-6, TNF- $\alpha$, dan MPC-1.

\section{KESIMPULAN}

Berdasarkan hasil penelitian dapat diambil kesimpulan bahwa pemberian infeksi bakteri $E$. coli menyebabkan mencit mengalami gejala diare dan penurunan berat badan yang signifikan. Ditemukan perbedaan signifikan pada nilai hematokrit dan jumlah leukosit total perlakuan asam humat dan isoprinosin lebih tinggi dibandingkan kontrol negatif dan kontrol normal.

Tidak terdapat perbedaan nyata pada berat limpa mencit antar perlakuan, namun pengamatan histologi menemukan perbedaan ukuran limpa mencit yang diinfeksi bakteri dan diberikan asam humat. Perbedaan jelas diamati pada ukuran pulpa putih, germinal center dan zona marginalis yang cukup besar. Pulpa merah pada perlakuan kontrol negatif ditemukan banyak sel limfosit yang menggerombol.

\section{UCAPAN TERIMA KASIH}

Penelitian ini didanai dari sumber dana DIPA 2017 Fakultas MIPA Universitas Tanjungpura, Pontianak.

\section{DAFTAR PUSTAKA}

Andrew UO, Ozoko LEC, Kingsley IA, Mamerhi ET, Beauty E (2017) Histologic effect of garlic extract on the spleen of adult wistar rat. J Pharm Biol Sci 12:1-4. doi:10.9790/30081204050104

Chen CH, Liu JJ, Lu FJ, Yang ML, Lee Y, Huang TS (2002) The effect of humic acid on the adhesibility on neutrophils. Thromb Res 108:67-76. doi:10.1016/S0049-3848(02)00384-5

Habibian R, Morshedi A, Delirezh N (2010) Effect of humic acid on humoral immune respons and phagocytosis. Global Veterinaria 4:135-139

IHSS (2015) Isolation of IHSS soil fulvic and humic acids. International Humic Substances Society. http://humicsubstances.org/isolation-of-ihss-soilfulvic-and-humic-acids/. Diakses 10 September 2015

Joone GK, Dekker J, van Rensburg CE (2003) Investigation of immunostimulatory properties of oxihumate. Z Naturforsch C 58:263267. doi:10.1515/znc-2003-3-421

Junek R, Morrow R, Schoenherr J, Schubert $\mathrm{R}$, Kallmeyer R, Phull S, Klocking $\mathrm{R}$ (2009) Bimodal effect of humic acids on the LPS-induced TNF- $\alpha$ release from differentiated U937 cells. Phytomedicine 16:470-476. doi: 10.1016/j.phymed.2008.10.003 
Kalia P, Kumar NR, Harjai K (2016) Effect of propolis extract on hematotoxicity and histological changes induced by Salmonella enterica serovar Typhimurium in balb/C mice. Arch Biol Sci 68:385-391. doi: 10.2298/ABS150902030K

Lasmi L (2013) Studi adsorpsi kompetitif logam $\mathrm{Ag}(\mathrm{I}), \mathrm{Cu}(\mathrm{II})$ dan $\mathrm{Cr}(\mathrm{III})$ pada asam humat. Tesis, FMIPA Universitas Gadjah Mada

Matheos C, Lintong P, Kairupan C (2013) Gambaran histologik jaringan limpa tikus putih (Rattus novergicus) yang diinfeksi Escherichia coli dan diberi madu. Jurnal e-Biomedik 1:961-965

Noor M (2001) Pertanian Lahan Gambut: Potensi dan Kendala. Penerbit Kanisius, Yogyakarta

Orlov DS (1995) Humic Substances of Soil and General Theory of Humification. AA Balkema Publisher, Rotterdam

Patil US, Jaydeokar AV, Bandawane DD (2012) Immunomodulators: A pharmacological review. Int J Pharm Pharm Sci 4:30-36

Rousdy DW dan Wijayanti N (2016) Peningkatan imunitas nonspesifik ikan mas, Cyprinus carpio (Linnaeus, 1758) yang diinfeksi Aeromonas hydrophilla dengan pemberian asam humat tanah gambut. Jurnal Iktiologi Indonesia 16:345-352

Rousdy DW, Rahmawati, Kurniatuhadi R (2016) Immune responses of wistar rat (Rattus novergicus) on adduction of humic acid from Borneo peat soil. Biosaintifika 8:400-405. doi: 10.15294/biosaintifika.v8i3.7499
Stevenson FJ (1994) Humus Chemistry, Genesis, Composition, Reaction. Second Edition. John Wiley \& Sons Inc, New York

Suvarna SK, Layton C, Bancroft JD (2013) Bancroft's Theory and Practice of Histological Techniques. Seventh Edition. Elsevier Ltd, Churchill Livingstone

Tasminatun S, Pravitasari R, Makiyah N (2017) Potential ethanol of Carica papaya $\mathrm{L}$. extract as immunomodulatory through histology observation at mice balb/C spleen. Berkala Kedokteran 13:205-210. doi: 10.20527/jbk.v13i2.4077

van Rensburg CEJ, Naude PJW (2009) Potassium humate inhibits complement activation and the production of inflammatory cytokines in vitro. Inflammation 32:270-276. doi: 10.1007/s10753-009-9130-6

Vašková J, Veliká B, Pilátová $M$, Kron I, Vaško $L$ (2011) Effects of humic acids in vitro. In Vitro Cell Dev Biol Anim 47:376-382. doi: 10.1007/s11626-0119405-8

Vetvicka V, Baigorri R, Zamarreno AM, Garcia-Mina JM, Yvin JC (2010) Glucan and humic acid: Synergistic effects on the immune system. J Med Food 13:863-869. doi: 10.1089/jmf.2009.0178

Winarni D, Handono CD, Sugiharto (2013) Efek Imunostimulatori beberapa fraksi teripang lokal Phyllophorus $s p$. terhadap histologi limpa mencit (Mus musculuc) yang diinfeksi Mycobacterium tuberculosis. Jurnal Ilmiah Biologi FST 1:1-13 